\title{
A Case of Multiple Myeloma Presenting with Neck Pain and Tetraparesis
}

\author{
Boyun Ağrısı ve Tetraparezi ile Prezente olan Multipl Myelom Olgusu \\ (1) Okan Balcancı, (1) Halil ibrahim Bekdemir*, (1) Ayhan Kul \\ Atatürk University Faculty of Medicine, Department of Physical Medicine and Rehabilitation, Erzurum, Turkey \\ *Şemdinli State Hospital, Clinic of Physical Medicine and Rehabilitation, Hakkari, Turkey
}

\section{To the Editor;}

86-year-old female patient applied to our clinic with complaints of weakness and neck pain in arms and legs that had been going on for a week. Her pain did not decrease with rest and did not respond to medical therapy. The pain in her neck did not affect her arms and she did not have comorbid neuropathic pain. In addition, muscle weakness had started. In the physical examination of the patient whose gait pattern was ataxic and who did not have a history of known trauma or operation, the neck region paravertebral area was found to be hard and sensitive with palpation. The patient who had diffuse 4/5 muscle strength had dermatomal hypoesthesia C4-C5 at both sides. The patient's deep tendon reflexes were hyperactive and her laboratory examination results were as follows: Hemoglobin $9.2 \mathrm{~g} / \mathrm{dL}$, C-reactive protein: $60 \mathrm{mg} / \mathrm{dL}$ and erythrocyte sedimentation rate: $100 \mathrm{~mm} / \mathrm{h}$. Platelet and white blood cell count and routine biochemical tests were normal. Cervical magnetic resonance imaging was requested for advanced examination of the patient whose direct graphy showed lytic lesion at C5. The mass in epidural region at C5 caused a pressure on the spinal cord and the posterior of C5 vertebra was compatible with posterior lytic appearance (Figure 1-2). In the post-operative examination of the patient who underwent laminectomy and decompression surgery at C4-C5, neurological deficit was found to recover. As a result of pathological examination and immunohistochemical tests, the patient was diagnosed with multiple myeloma (Kappa subtype). Monoclonal immunoglobulin (Ig) $G$ was found to increase in blood and urine protein electrophoresis analysis, while other immunoglobulins were found to decrease. Levels of serum $\lg$ were $\lg \mathrm{A}: 0.67, \operatorname{lgM}: 0.4 \mathrm{~g} / \mathrm{L}$ and $\operatorname{lgG}: 50 \mathrm{~g} / \mathrm{L}$, respectively. There was Bence Jones protein in the urine. Bone marrow aspiration consisted of $45 \%$ plasma cells. The patient who received triple chemotherapy combination and zoledronic acid therapy responded positively to the therapy. The patient is being followed by our clinic and she is continuing her followups with a good general medical condition, decreased pain and normal physical examination.

In neck, back and low-back pain resistant to treatment, primary tumours of the spine and tumour cases which affect the spine as a result of metastasis should be kept in mind $(1,2)$. Multiple myeloma results from plasma cells which infiltrate the bone marrow and synthesize abnormal immunoglobulin (3). Laboratory examinations of multiple myeloma, which is the malignant tumour that involves the bone most, depend on bone marrow involvement. Pain is the most primary symptom. The disease, which is quite rare before the age of 40 is generally more frequent between 50 and 70 years of age and in men (3). The source of pain is lytic bone lesions

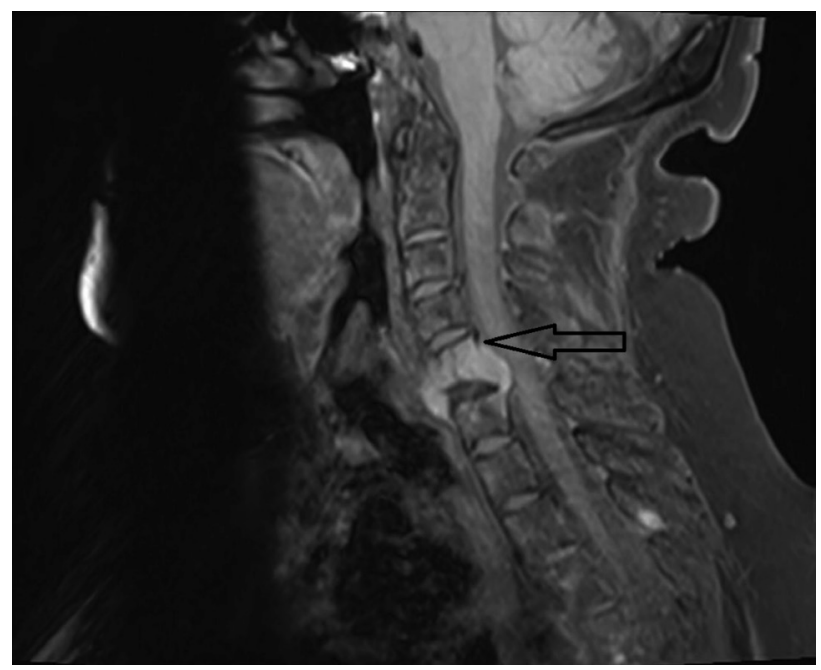

Figure 1. An infiltrative lesion with contrast enhancement was observed in the T1 sequence in which the $\mathrm{C} 5$ vertebra infeiror and $\mathrm{C} 6$ vertebra superior end-platelets were bridged in the corpus anteriorposterior corners

Address for Correspondence/Yazışma Adresi: Okan Balcancı MD, Atatürk University Faculty of Medicine, Department of Physical Medicine and Rehabilitation, Erzurum, Turkey

Phone: +90 5374494638 E-mail: okan5590@hotmail.com ORCID ID: orcid.org/0000-0002-0937-5277 Received/Geliş Tarihi: 12.03.2019 Accepted/Kabul Tarihi: 31.07.2019

${ }^{\circ}$ Copyright 2020 by the Turkish Osteoporosis Society / Turkish Journal of Osteoporosis published by Galenos Publishing House. 


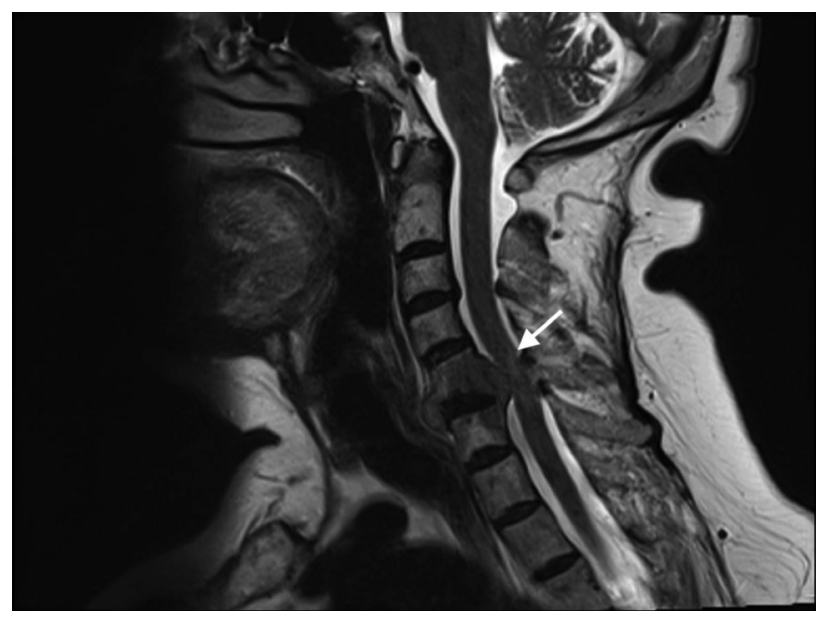

Figure 2. Increased signal in T2 series compatible with myelomalacia secondary to compression medulla spinalis was observed

or osteopenia related compression fractures. The pain, which has a mechanical character and which is intermittent at the beginning, becomes steady as the disease advances. Localized pain can also occur with the growth of tumour to spinal cord or root. In our case, pain occurred as a result of both lytic lesions and pressure of the tumour to spinal cord. Spine is the most frequent involvement site; however, the involvement of cervical area seen in our patient is rare (4). Involvement in the spine is $59 \%$ thoracic, $31 \%$ lumbar and $10 \%$ cervical. Then flat bones, which are rich in bone marrow, involve the pelvis, skull, costas, clavicle and scapula. Diaphysis of proximal long bones is also among areas that can be involved. However, knee and lower elbow involvement occurs only in $10 \%$ of the patients (5). Following surgical excision, local radiotherapy and combined chemotherapy are preferred in its treatment depending on the clinic. As a conclusion, although multiple myeloma is rare, it should be considered in the definitive diagnosis of pain resulting from cervical area.

Keywords: Multiple myeloma, neck pain, tetraparesis Anahtar Kelimeler: Multipl miyelom, boyun ağrısı, tetraparezi

\section{Ethics}

Peer-review: Externally and internally peer-reviewed.

\section{Authorship Contributions}

Surgical and Medical Practices: O.B., H.I.B, Concept: O.B., A.K., H.I.B., Design: O.B., Data Collection or Processing: O.B., A.K., Analysis or Interpretation: O.B., A.K., H.I.B., Literature Search: O.B., Writing: O.B.

Conflict of Interest: No conflict of interest was declared by the authors.

Financial Disclosure: The authors declared that this study received no financial support.

\section{References}

1. Bağcıer F, Osman O, Akın E. Sırt Ağrısı ile Prezente Olan Akciğer Kanseri: Bir Metastaz Olgusu. Turk J Osteoporos 2016;22:50-3.

2. Ciftdemir M, Kaya M, Selcuk E, Yalniz E. Tumors of the spine. World J Orthop 2016;7:109-16.

3. Barlogie B, Shaughnessy J, Munshi N, Epstein J. Plasma cell myeloma. In: Beutler E, Lichtman M, Coller BS, Kipps TJ, Seligsohn $U$, editors. Williams hematology. 6th ed. New York: McGraw-Hill; 2001. p. 1279-304.

4. Rao G, Ha CS, Chakrabarti I, Feiz-Erfan I, Mendel E, Rhines LD. Multiple myeloma of the cervical spine: treatment strategies for pain and spinal instability. J Neurosurg Spine 2006;5:140-5.

5. Greenspan A. Malignant bone tumors II. In: Greenspan A, editor. Orthopedic radiology: a practical approach. 3rd ed. Philadelphia, Pa: Lippincott Williams\& Wilkins; 2000. p. 697-700. 